\title{
Effects of Namya Kanom Jeen powder extracts on antioxidative and anti-inflammatory properties
}

\author{
Preeya Dat-arun ${ }^{1}$, Rattana Leelawattana ${ }^{2}$, and Pavinee Chinachoti ${ }^{3}$
}

${ }^{1}$ Interdisciplinary Graduate School of Nutraceutical and Functional Food, Learning Resource Center, Prince of Songkla University, Hat-Yai, Songkhla, 90110, Thailand; ${ }^{2}$ Division of Endocrinology and Metabolism, Department of Medicine, Faculty of Medicine, Prince of Songkla University, Hat- Yai, Songkhla, 90110, Thailand; ${ }^{3}$ Quest, Ltd. 2/1 Soi Areesampun Rama 6 Rd, Payathai, Bangkok 10400, Thailand

Corresponding author: Professor Dr. Pavinee Chinachoti, Quest, Ltd. 2/1 Soi Areesampun Rama 6 Rd, Payathai, Bangkok 10400, Thailand

Submission Date: August $7^{\text {st }}, 2017$, Acceptance Date: August $28^{\text {th }}, 2018$, Publication Date: August $31^{\text {st }}, 2018$

Citation: Dat-arun P., Leelawattana R., Chinachoti P. Effects of Namya Kanom Jeen powder extracts on antioxidative and anti-inflammatory properties. Functional Foods in Health and Disease 2018; 8(8): 424-437. DOI: https://doi.org/10.31989/ffhd.v8i8.383

\section{ABSTRACT}

Background: Spices and herbs are known to have antioxidant and anti-inflammatory properties. We studied their properties of Namya Kanom Jeen (NKJ), a spicy soup (Southern Thailand recipe) with water and ethanol (50\% and 95\%) extracts.

Aim: To assess functional properties, antioxidant, $\alpha$-amylase inhibition, and anti-inflammatory properties, of $N K J$ powder extract using in vitro model

Methods: Antioxidant activities were determined using free radical scavenging activity (DPPH) and Ferric Reducing Antioxidant Power (FRAP). Anti-inflammation effect was studied by measuring nitric oxide (NO) production inhibition on RAW264.7 macrophage cells after being exposed to lipopolysaccharide (LPS).

Results: Water extract of $N K J$ powder demonstrated the highest activity in anti-inflammatory and antioxidant property by DPPH radical scavenging activity when compared with ethanol extract.

Conclusion: The combined effect of several bioactive compounds within NKJ powder extracts may ameliorate the oxidation and inflammation. 
Keywords: Antioxidant, Anti-inflammation, Phenolic compound, Namya Kanom Jeen powder

\section{INTRODUCTION}

Aerobic metabolism of cells is an oxidative process which often creates free radicals. Reactive oxygen species (ROS) as well as reactive nitrogen species (RNS) are produced [1] partly as protection mechanisms. The free radicals produced can have harmful effects on human health. At low or moderate concentration, ROS and RNS provide a counter-active, beneficial effect to cellular response and immune function. At high levels, they may impose oxidative stress to cells and tissues since they act as mediators promoting the damage to cellular components, including lipids, proteins, and DNA [2-3]. Prolonged oxidative stress triggers chronic inflammation in cells and tissues leading to increased risks of metabolic syndrome diseases, such as cancer, diabetes, and cardiovascular diseases [4].

Antioxidants are compounds that neutralize free-radicals and other pro-oxidative intermediates of cells. These actions can potentially reduce the progression of inflammation and its related diseases. This is accomplished by two principle mechanisms of action which are mainly involved. First, there is a chain-breaking mechanism, by which the primary antioxidant donates electrons to the free radicals present in the systems. Second, there is the removal of ROS/RNS initiators (secondary antioxidants) by quenching of the chain-initiating catalyst [5]. An antioxidative compound can block the inflammation process by inhibiting the nitric oxide (NO) released by suppressing inducible expression of nitric oxide synthase (iNOS) and/or its activity; NO reduction is frequently mediated by NF- $\kappa \mathrm{B}$ inhibition [6].

Phytochemicals from plants, such as herbs and spices, are rich in antioxidant activity [7]. Some of these phytochemicals demonstrate the ability to reduce inflammation and are potential candidates for intervention or preventative treatments of metabolic disorders or metabolic syndromes [8]. There has been widespread investigation and research surrounding food properties that can delay oxidation and reduce inflammation. Accordingly, there have been many studies conducted on individual plants or extracted compounds [9]. However, the combined effects of daily food consumption and whole food (mixture) have not been studied in indigenous Southern Thai foods, which are known to be rich in herbs and spices. Thus, it has been speculated that food bioactive components may work synergistically to exert the benefits of health functions via multiple pathways [10].

The extraction of bioactive compounds from food or plants sources uses organic solvents (ethanol, methanol, acetone, and diethyl ether). In this study, we are particularly interested in water extraction, since we consume food in presence of water. Bioactive recovery mainly depends on the type of solvent and the extraction methods being adopted [11]. Therefore, comparisons between these different solvent extractions are necessary in order to determine the relative differences in their activities.

Although various herbs and spices have been long reported to individually exhibit antioxidative and anti-inflammatory properties, evidence is still lacking on whole foods, which are traditionally consumed as a whole dish. The positive effects of some specific Thai food in in vitro and in vivo models have been reported. Tuntipopipat and colleague discovered that red curry paste ethanol extract decreased NO production and iNOS expression, while also suppressing COX-2, 
TNF- $\alpha$, and IL-6 in lipopolysaccharide-activated murine macrophage cell line [12]. Prangthip and co-workers reported how Thai Red Curry Paste (TRCP) extracts decrease baseline blood glucose, liver enzyme activities, hyperinsulinemia, serum malondialdehyde, and ROS in diabetic rats [13]. However, the greater challenge is discovering the probable effects of indigenous food that could potentially relieve a progressive effect of degenerative diseases via antioxidative and antiinflammatories properties.

Based on our earlier screening, 12 Southern Thai foods, NKJ (Namya Kanom Jeen extract) ranked higher in biological properties [14]. These foods were the basis of this study. Thus, the objectives of this study were to determine various types of solvent on $N K J$ extracts in terms of phenolic contents, antioxidant, and anti-inflammatory properties.

\section{MATERIALS AND METHODS}

\section{Chemicals and reagents}

2,2-Diphenyl-1-picrylhydrazyl (DPPH), 2,4,6-tripyridyl-s-triazine (TPTZ), ferric chloride hexahydrate $\left(\mathrm{FeCl}_{3} \bullet 6 \mathrm{H}_{2} \mathrm{O}\right)$, gallic acid, protocatechuic acid, $p$-coumaric acid, chlorogenic acid, ferulic acid, capsaicin, and L-Nitro-arginine were purchased from Sigma-Aldrich Corporation (St. Louis, Missouri, USA). Folin-Ciocalteu's phenol reagent, sodium acetate, hydrochloric acid, sodium carbonate $\left(\mathrm{Na}_{2} \mathrm{CO}_{3}\right)$, and $99.5 \%$ absolute ethanol were purchased from Merck Millipore (Darmstadt, Germany). Roswell Park Memorial Institute medium (RPMI medium), lipopolysaccharides (LPS), phosphate buffered saline (PBS), fetal bovine serum (FBS), penicillin, streptomycin, and $0.25 \%$ trypsin-EDTA were purchased from Gibco (Carlsbad, California, USA). All chemicals and reagents were of analytical or HPLC grade.

\section{Sample preparation: Namya Kanom Jeen (NKJ)}

Namya Kanom Jeen (NKJ) consisting of $34.2 \%(\mathrm{w} / \mathrm{w})$ of boiled and deboned fish, $1.0 \%$ dry hot chili (Capsicum frutescens Linn.), 1.4\% garlic (Allium sativum Linn.), 0.2\% turmeric (Curcuma Longa Linn), 1.0\% lemongrass (Cymbopogon citratus Stapf), 0.5\% pepper (Piper nigrum Linn.), $1.5 \%$ shallot (Allium ascalonicum Linn.), $0.7 \%$ fermented shrimp paste, $58.25 \%$ coconut milk, $0.34 \%$ garcinia (Garcinia Cambogia), $0.21 \%$ salt, and $0.7 \%$ kaffir lime (Citrus hystrix DC.) leaves. All ingredients were obtained from the Plaza Market at Hatyai, Songkhla Province in 3 batches of cooking process. The cooking method consisted of preparation in a Thai kitchen, following traditional methods modified from Charoenkiatkul and co-workers [15]. The coconut milk was heated to a boil and followed by the addition of ground fish, which was mixed with the curry paste, stirred, and cooked at $75-90^{\circ} \mathrm{C}$ for $40 \mathrm{~min}$. Salt and garcinia were added, and the dish was topped with kaffir lime leaves.

Five hundred grams of finished $N K J$ was blended (Panasonic Blender MX 151 SP, Japan) and freeze-dried (0.055 mbar, $12 \mathrm{~h}$, at $-40^{\circ} \mathrm{C}$, Dura Dry, Dura Freeze Dryer, Canada). The dried samples (moisture content $2.25 \pm 0.02 \%$ ) were milled to fine (20 mesh sieve) powders ( $3 \mathrm{~s}$, Super Blender, AIKO, China) and stored in plastic bottles with screw caps at $-20^{\circ} \mathrm{C}$ until extraction and proximate analyses. 


\section{Proximate analyses of freeze dried samples}

The proximate analyses: moisture, ash, protein, fat and crude fiber contents [16] and mineral contents (including iron, zinc, sodium, calcium, magnesium, potassium and phosphorus) were determined by modified AOAC 990.08 [16] by using digestion of wet samples with nitric acid, followed by inductively coupled plasma atomic emission spectrometric measurement (ICP-AES, Perkin Elmer, USA).

\section{Preparation of foods extracts for functional properties}

$N K J$ powder demonstrated very high contents of fat content; the food samples were first defatted with hexane before extraction (to final content of fats is $2.45 \mathrm{~g} / 100 \mathrm{~g}$ dry food sample) with water.

Oil in food matrix can be affected by the method of analysis as antioxidant activity due to its sensitivity to oxidation. Consequently, the process of lipid peroxidation can lead to disturbances in the membrane structure and functionality [17]. Hexane is the preferred solvent to remove the oil; hexane-based processes have been in commercial operation for a long time. For such processes, it is possible to achieve oil yields in excess of $95 \%$ with a solvent recovery of over $95 \%$. However, in food production cases, hexane extraction is approved as long as no trace of hexane remains in the final product $[18,19]$. Further research should be conducted in order to explore the use of more gentle processes such as supercritical fluid extraction.

Freeze-dried $N K J$ sample was first extracted with hexane at 1:10 (w/v powder/hexane) ratio before mixing for 30s (Vortex-mixer Genie 2 G560E, Scientific Industries, USA), and sonicated for 15 min (Digital Ultrasonic Cleaner 4820, Blazer, USA). After centrifugation $(2,432 \times g$, Hettich Zentrifugen, MIKRO 22R, Buckinghamshire, U.K.), pellets were extracted with hexane again 2 more times. After being left to dry at $30^{\circ} \mathrm{C}$ (ambient air) for $30 \mathrm{~min}$, each pellet sample was divided in three equal portions for further extraction by 3 solvents (water, 50\% and $95 \%$ ethanol in water) at dried pellet: solvent ratio of 1:30 (w/v). After being shaken for $1 \mathrm{~h}$ ambient at $120 \mathrm{rpm}$ (WiseShake ${ }^{\circledR}$, SHO-2D, Wertheim, Germany), each aliquot was centrifuged at $2,432 \times g$ for 15 $\min$ at $4^{\circ} \mathrm{C}$. The supernatant fractions were evaporated under vacuum $\left(175 \mathrm{mmHg}, 45-50^{\circ} \mathrm{C}\right)$ for $30 \mathrm{~min}$ before being freeze-dried (with the same condition as above) and stored in brown bottles at $-20^{\circ} \mathrm{C}$ until analyzed.

\section{Antioxidant activities:}

\section{DPPH radical scavenging property assay}

DPPH was measured from a decoloration of 2,2 diphenyl-1-picrylhydrazyl (DPPH) radical of food extracts by the method modified from Brand-William [24] using gallic acid standard solutions (containing 2, 4, 6, 8 and $10 \mu \mathrm{g} / \mathrm{ml}$ of gallic acid in distilled water). One hundred $\mu 1$ of food extract samples and a gallic acid standard solutions were individually placed in a 96-well microtiter plate. One hundred $\mu$ l of DPPH solution $(0.2 \mathrm{mM}$ in ethanol) and the mixtures were added and left at room temperature for $30 \mathrm{~min}$ in darkness. Absorbance $(517 \mathrm{~nm}$ ) was measured using a microplate reader under a control solution of $100 \mu \mathrm{l}$ distilled water and $100 \mu \mathrm{l}$ of $0.2 \mathrm{mM}$ DPPH. Ascorbic acid was used as a positive control. The percentage of radical scavenging ability was calculated using the following equation (1) 


$$
\text { Scavenging activity }(\%)=\left[1-\mathrm{A}_{\text {sample }} / \mathrm{A}_{\text {control }}\right] \times 100 \text { Equation (1) }
$$

Where $\mathrm{A}_{\text {control }}=$ absorbance of control reaction

$\mathrm{A}_{\text {sample }}=$ absorbance of the sample extracts

Analyses were performed in triplicates. The sample concentration providing $50 \%$ inhibition $\left(\mathrm{IC}_{50}\right)$ was calculated from the graph of inhibition percentage against sample concentration in linear regression.

\section{FRAP assay}

FRAP assay was determined according to the method of Benzie and Strain [21]. Stock solutions containing $300 \mathrm{mM}$ acetate buffer (pH 3.6), $10 \mathrm{mM}$ 2,4,6-tri[2-pyridyl-s-triazine] (TPTZ) solution in $40 \mathrm{mM} \mathrm{HCl}$, and $20 \mathrm{mM} \mathrm{FeCl}_{3} .6 \mathrm{H}_{2} \mathrm{O}$ were prepared. Acetate buffer $(25 \mathrm{ml})$, TPTZ solution (2.5 $\mathrm{ml}$ ), and $\mathrm{FeCl}_{3} \cdot 6 \mathrm{H}_{2} \mathrm{O}$ solution $(2.5 \mathrm{ml})$ were then mixed and incubated at $37^{\circ} \mathrm{C}$ for $30 \mathrm{~min}$ in a warm water bath prior to use. This was referred to as a FRAP solution. Food extract samples were diluted with distilled water to $1,2,3,4$, and $5 \mathrm{mg} / \mathrm{ml}$ concentrations. Thirty $\mu$ l each of these diluted food extracts was placed in a 96-well mircrotiter plate. Thirty $\mu$ l of Trolox standard solutions (5, $10,25,50,100$, and $200 \mu \mathrm{M} / \mathrm{ml}$ in ethanol were placed in other empty wells. FRAP solution (270 $\mu \mathrm{l}$ ) was added to both food extracts and standard wells, kept for $30 \mathrm{~min}$ in darkness, and assayed in triplicate. In this reaction, ferric-tripyridyltriazine ( $\left.\mathrm{Fe}^{3+}-\mathrm{TPTZ}\right)$ complex is reduced from ferric (yellow) to ferrous (blue) form. Development of ferrous tripyridyltriazine complex was measured by absorbance at $595 \mathrm{~nm}$ using a microplate reader (Microplate reader, Biotek, Power wave X, Winooski, USA) using Trolox standard curve $\left(\mathrm{Y}=0.041 \mathrm{x}+0.1124, \mathrm{r}^{2}=0.997\right)$. The results were expressed as $\mu$ mole Trolox/g dry crude extract/

\section{Anti-inflammatory activity and cytotoxicity in macrophage $R A W 264.7$ cell lines}

NO inhibitory effect was performed in Macrophage Raw 264.7 cells [22]. Macrophage RAW 264.7 cell line was cultured in RPMI medium supplemented with $10 \%$ heat-inactivated fetal bovine serum, Penicillin $(100 \mathrm{U} / \mathrm{ml})$, and Streptomycin $(100 \mathrm{mg} / \mathrm{ml})$, which were maintained in a humidified incubator with 5\% $\mathrm{CO}_{2}$. RAW 264.7 cells were harvested by scraper and diluted to make a suspension in a fresh medium. The cells were then seeded in 96-well plates $\left(1 \times 10^{6}\right.$ cells/well) and allowed to adhere for $2 \mathrm{~h}$ at $37^{\circ} \mathrm{C}$ in a humidified atmosphere containing $5 \% \mathrm{CO}_{2}$. The old medium was replaced with $0.1 \mathrm{ml}$ fresh medium containing $1 \mu \mathrm{g} / \mathrm{ml}$ of LPS from Escherichia coli, serotype 055:B5. Medium wells containing $0.1 \mathrm{ml}$ food extract with various concentrations in deionized water $(1,10,100,1000 \mu \mathrm{g} / \mathrm{ml})$ were prepared and incubated for $24 \mathrm{~h}$. The positive control were cells with no food extract but with LPS, while the negative control was no food extract or LPS. Nitrite in the culture medium was detected using a reaction with Griess reagent. One hundred $\mu 1$ of supernatant was mixed with $100 \mu 1$ of Griess reagent and the optical density (OD) was detected at $570 \mathrm{~nm}$. Inhibition (\%) of NO production was determined according to equation (2).

Cell viability was also measured using 3-(4,5-dimethyl-2-thaizoly)-2,5-diphenyltetrazolium bromide (MTT) reagent, which was absorbed into the living RAW 264.7 cells and converted into formazan according to the method of Yamamoto and team [23]. 
The 96-well plates from above (at a density of $1 \times 10^{6}$ cells per well) were added with $10 \mu 1$ MTT solution [5 mg/ml in PBS] then incubated at $37^{\circ} \mathrm{C}$ with $5 \% \mathrm{CO}_{2}$ for $2 \mathrm{~h}$. The medium was then removed. Isopropanol containing $100 \mu \mathrm{l} 0.04 \mathrm{M} \mathrm{HCl}$ was added to dissolve the formazan produced in the cells. Optical density of the formazan solution was measured with a microplate reader at $570 \mathrm{~nm}$. Cell survival (\%) was calculated according to equation (3). L-Nitro-arginine (LNA) was used as a positive control.

$$
\text { NO Inhibition }(\%)=[(\mathrm{C}-\mathrm{BC})-(\mathrm{S}-\mathrm{BS}) /(\mathrm{C}-\mathrm{BC})] \times 100 \ldots \ldots . . \text { Equation }(2)
$$

Where $\mathrm{C}$ is absorbance of the Control [LPS $(+)$, Sample $(-)$ ]; BC is absorbance of the Blank Control [LPS (-), Sample (-)]; S is absorbance of the test sample [LPS (+), Sample (+)]; BS is absorbance of Blank Sample [LPS $(-)$, Sample $(+)]$

$$
\begin{aligned}
& \text { Cell survival }(\%)=(\text { OD sample } / \text { OD control }) \times 100 \quad \text { Equation }(3) \\
& \text { Where } \quad \mathrm{C}=\text { Control }-- \text { RPMI }+ \text { LPS } \\
& \text { S }=\text { Sample }-- \text { Sample }+ \text { LPS }
\end{aligned}
$$

\section{$\alpha$-Amylase inhibition assay}

Inhibition of $\alpha$-amylase assay was determined by Manaharan's team [24]. One ml of extract and $0.05 \mathrm{ml} 0.02 \mathrm{M}$ sodium phosphate buffer $(\mathrm{pH} 6.9$ with $0.006 \mathrm{M} \mathrm{NaCl})$ containing porcine $\alpha$-amylase $(0.5 \mathrm{mg} / \mathrm{ml})$ were mixed and incubated at $25^{\circ} \mathrm{C}$ for $10 \mathrm{~min}$. Fifty $\mu 1$ of $1 \%$ starch solution in $0.02 \mathrm{M}$ sodium phosphate buffer was then mixed and the reaction mixture incubated at room temperature for $10 \mathrm{~min}$ before stopping with $0.2 \mathrm{~mL}$ of dinitrosalicylic acid color reagent. After being incubated in boiling water bath ( $5 \mathrm{~min}$ ) and cooled to room temperature, the reaction mixture was diluted (1 $\mathrm{ml}$ of distilled water) and an absorbance at $520 \mathrm{~nm}$ was measured. $\alpha$-Amylase inhibition activity was expressed as percentage inhibition which was calculated as the following:

$$
\%=\frac{\text { Absorbance of blank }- \text { Absorbance of sample }}{\text { Absorbance of blank }} \text { Equation (4) }
$$

\section{Total phenolic content (TPC)}

TPC were determined according to Slinkard and Singleton [25]. Food extracts were diluted with distilled water at concentrations of $0.1,0.5,1,2,3,4,5$. Sample solutions (12.5 $\mu \mathrm{l})$ and standard solutions (containing 5, 10, 25, 50, 100, 125, r150 and $200 \mu \mathrm{g} / \mathrm{ml}$ of gallic acid in distilled water) were individually placed in a 96- well microtiter plate. Reagent blank was distilled water. FolinCiocalteau phenol reagent $(12.5 \mu \mathrm{l})$ was added to each well and left for $6 \mathrm{~min}$. The calculated $\mathrm{Na}_{2} \mathrm{CO}_{3}$ solution $(125 \mu \mathrm{l}$ of $7 \% \mathrm{w} / \mathrm{v}$ in distilled water) was mixed in together with $100 \mu \mathrm{l}$ of distilled water and the mixture allowed to stand for $90 \mathrm{~min}$ in darkness and absorbance measured at $760 \mathrm{~nm}$. Gallic acid was used to make standard curve. Each crude extract was analyzed in triplicates and the results expressed in mg of gallic acid equivalents (GAE) per g dry crude extract.

\section{HPLC analysis}

Phenolic acid standards consisted of gallic acid, protocatechuic acid, $p$-coumaric acid, chlorogenic acid, and ferulic acid. Solutions were made by dissolving $0.01 \mathrm{~g}$ of each in $10 \mathrm{ml}$ distilled water. 
Aliquots of $0.5 \mathrm{ml}$ of each solution were put in $5.0 \mathrm{ml}$ volumetric flasks and made to volume with distilled water. Working solutions were prepared to make individual solution of $1,5,12.5,25$, and $50 \mu \mathrm{g} / \mathrm{ml}$ of gallic, protocatechuic, $p$-coumaric, chlorogenic, and ferulic acids.

Defatted dried crude samples $(0.01 \mathrm{~g})$ were solubilized in $2 \mathrm{ml}$ of acid methanol $(62.5 \%$ methanol: $6 \mathrm{M} \mathrm{HCl}, 4: 1 \mathrm{v} / \mathrm{v}$ ) and shaken at $70^{\circ} \mathrm{C}$ for $2 \mathrm{~h} \mathrm{[26].} \mathrm{A} \mathrm{reversed-phase} \mathrm{High} \mathrm{Performance}$ Liquid Chromatography (HPLC) method [27] with modification was used to characterize the phenolic compounds in the extracts. After filtered through a $0.20-\mu \mathrm{m}$ pore size, a $10-\mu 1$ aliquot was separated in an HPLC system (Agilent 1200, Waldbronn, Germany) equipped with a diode array detector on a $250 \mathrm{~mm} \times$ aliquot was separated in diode array detector on a $250 \mathrm{~mm} \times 4.6 \mathrm{~mm}$ i.d., $5 \mu \mathrm{m}$, Eclipse XDB-C18, analytical column (Agilent, Santa Clara, CA, USA).

The mobile phase was purified water with $0.1 \%(\mathrm{v} / \mathrm{v})$ trifluoroacetic acid (TFA, solvent A), and acetonitrile (solvent B) was at a flow rate of $0.8 \mathrm{ml} / \mathrm{min}$. Gradient elution was performed as the following: from 0 to $5 \mathrm{~min}$, linear gradient from 5 to $9 \%$ of solvent B; from 5 to $15 \mathrm{~min}, 9 \%$ solvent B; from 15 to 22 min linear gradient from 9 to $11 \%$ solvent B; from 22 to 35 min, linear gradient from 5 to $18 \%$ solvent $\mathrm{B}$, and from 35 to $42 \mathrm{~min}, 18 \%$ solvent B. Column temperature was controlled at $40^{\circ} \mathrm{C}$.

Hydroxybenzoic acid compounds (gallic acid and protocatechuic acid) were detected at 290 $\mathrm{nm}$ and hydroxycinnamic (chlorogenic acid, $p$-coumaric acid, and ferulic acid) at $325 \mathrm{~nm}$.

For the separation of capsaicin according to the method used by Othman's team [28], by HPLC we used isocratic program composing of 50\% solvent A (0.1\% TFA in water) and 50\% solvent $B$ (acetonitrile) at flow rate $1 \mathrm{ml} / \mathrm{min}$, temperature set up at $30^{\circ} \mathrm{C}$. A reverse phase $250 \mathrm{~mm}$ $\times 4.6$ mm i.d., $5 \mu \mathrm{m}$, Eclipse XDB-C18, analytical column (Agilent, Santa Clara, CA, USA) and detected at $280 \mathrm{~nm}$.

\section{Statistical analysis}

All analyses were carried out in triplicates and reported as means \pm standard deviation. Data were analyzed by analysis of variance (ANOVA) and statistical significance with Duncan's multiple range test $(\mathrm{P}<0.05)$.

\section{RESULTS AND DISCUSSION}

\section{Chemical composition of $\mathrm{NKJ}$}

On $100 \mathrm{~g}$ dry basis, freeze-dried $N K J$ powder showed $2.25 \pm 0.02 \mathrm{~g}$ moisture, $24.33 \pm 0.11 \mathrm{~g}$ protein, $51.96 \pm 0.11 \mathrm{~g}$ fat, $8.86 \pm 0.05 \mathrm{~g}$ ash, $1.67 \pm 0.30 \mathrm{~g}$ dietary fiber and $12.60 \pm 0.01 \mathrm{~g}$ carbohydrate. Iron, zinc, sodium, calcium, magnesium, potassium and phosphorus were $45.54 \pm 0.74,16.19 \pm 0.00$, $12,762.94 \pm 102.57,1,494.99 \pm 0.12,1,063.44 \pm 8.71,45.58 \pm 0.74$, and $2,656.93 \pm 26.78 \mathrm{mg} / \mathrm{kg}$ dry sample respectively.

\section{Antioxidant activities:}

\section{DPPH radical scavenging property}

Free radical scavenging capacity (DPPH) data for defatted $N K J$ extracted with water, $50 \%$ ethanol and $95 \%$ ethanol are shown in Table 1 . The $N K J$ extracts free radical scavenging (DPPH) activity 
were highest in water soluble extract $68.34 \pm 5.11 \%$. Accordingly, $\mathrm{IC}_{50}$ of DPPH values of $N K J$ water soluble extract was the lowest $(85.50 \pm 0.71 \mu \mathrm{g} / \mathrm{g}$ dry crude extract), followed by $50 \%$ and 95\% ethanol extracts. As a result, the DPPH activities from the result obtained clearly revealed that scavenging properties increased with water as the solvent used. Thus, in the food studied, the hydrophilic components appeared to dominate free radical scavenging ability as compared with the more hydrophobic component (water insoluble). Food components that may exert scavenging activity such as ascorbic acid present in chili [29] and soluble organosulfur compounds are present in garlic [30], which are some of the major herbs used.

Table 1. Antioxidant properties of $N K J$ extracted.

\begin{tabular}{lccc}
\hline $\begin{array}{l}\text { Ethanol } \\
\text { extraction }\end{array}$ & $\begin{array}{c}\text { \% scavenging }(\mathrm{DPPH}) \\
\text { activity }(\text { at } 1 \mathrm{mg} \text { crude } \\
\text { extract/ml })\end{array}$ & $\begin{array}{c}\mathrm{IC}_{50} \text { of DPPH }(\mu \mathrm{g} / \mathrm{g} \\
\text { dry crude extract })\end{array}$ & $\begin{array}{c}\text { FRAP }(\mu \mathrm{mole} \text { Trolox } \\
\text { Equivalent/g dry crude } \\
\text { extract) }\end{array}$ \\
\hline $\begin{array}{l}\text { 0\% ethanol } \\
\text { (Water) }\end{array}$ & $68.34 \pm 5.11^{\mathrm{a}}$ & $85.50 \pm 0.71^{\mathrm{a}}$ & $1.82 \pm 0.04^{\mathrm{a}}$ \\
$50 \%$ ethanol & $25.27 \pm 1.52^{\mathrm{b}}$ & $252.53 \pm 10.99^{\mathrm{b}}$ & $1.23 \pm 0.00^{\mathrm{a}}$ \\
$95 \%$ ethanol & $13.39 \pm 1.23^{\mathrm{c}}$ & $258.50 \pm 9.19^{\mathrm{b}}$ & $3.96 \pm 0.05^{\mathrm{b}}$ \\
\hline
\end{tabular}

All data are present as mean \pm standard deviation of 3 replicates

Values in the same column followed by the same lowercased letter are not significantly different by Duncan's Multiple-Rage Test ( $p$-value < 0.05).

\section{Ferric Reducing Antioxidant Power- FRAP}

FRAP or the ability to reduce Fe (III) to Fe (II) are shown in Table 1. In this study, $N K J$ extracted with $95 \%$ ethanol exhibited the highest reducing activity $(3.96 \pm 0.05 \mu$ mole TE/g dry crude extract, Table 1). There was no significant difference between NKJ extracted with water and $50 \%$ ethanol.

In contrast, Liu and their colleagues [31] reported a reversed order of activities of tea (Camellia sinensis) leaves, i.e., that polyphenolic and antioxidant activities were in the following order (in $\mathrm{mM} \mathrm{FeSO}_{4} / \mathrm{g}$ dry weight): ethanol extract (6.7) > n-butanolic extract (4.7) > chloroform extract (4.2) > water extract.

\section{$\alpha$-Amylase inhibition activity}

The inhibitory effect on $\alpha$-amylase enzyme activity were all high for the three solvent extracts ranging from $67.39 \pm 1.8 \%$ to $91.91 \pm 0.65 \%$ as shown in Table $2.95 \%$ ethanol extract was highest in $\alpha$-amylase inhibition ( $92 \%$ ) followed by water extract $(87 \%)$. (2S, 3R)-Hydroxyl citric acid (HCA) compound in garcinia has been reported to have pancreatic $\alpha$-amylase and intestinal $\alpha$ glucosidase inhibitory effect [32].

\section{Anti-inflammatory property of NKJ extracts}

Production of pro-inflammatory mediator, NO, in LPS-stimulated RAW264.7 cells was monitored with treatments of $N K J$ extracts. Cell viability data indicated $>80 \%$ viability (Figure 1A), demonstrated that $N K J$ extracts had no adverse cytotoxicity effect on RAW264.7 cells. 
NO inhibition was significant but differed significantly in degree of inhibition with water extract being most effective and 95\% ethanol extract the least (Figure 1B). Table 2 showed that the water extract was lowest in $\mathrm{IC}_{50}, 0.003 \mu \mathrm{g} / \mathrm{g}$ dry crude extract, whereas $50 \%$ and $95 \%$ ethanol extracts were 0.424 and $0.838 \mu \mathrm{g} / \mathrm{g}$ dry crude extract, respectively. This result paralleled with antioxidant activities by DPPH radical scavenging in $\mathrm{IC}_{50}$ (Table 1 , but not proportionally) demonstrated that the water-soluble fraction was lowest in $\mathrm{IC}_{50}$. Figure $1 \mathrm{~B}$ also demonstrated relative increase in NO inhibition with all extracts, particularly with the water extracts showing the strongest increase reaching $100 \%$ inhibition at $1 \mathrm{mg} / \mathrm{ml}$.

Table 2. $\alpha$-Amylase inhibition (\%), NO production inhibition $\left(\mathrm{IC}_{50}\right)$, total phenolic contents and some type of phenolic compound of $N K J$ extract

\begin{tabular}{|c|c|c|c|c|c|c|}
\hline $\begin{array}{l}\text { Ethanol } \\
\text { extraction }\end{array}$ & $\begin{array}{c}\text { \% } \alpha- \\
\text { Amylase } \\
\text { inhibition }\end{array}$ & $\begin{array}{l}\text { Inhibition of NO } \\
\text { production }\left(\mathrm{IC}_{50}, \mu \mathrm{g} / \mathrm{g}\right. \\
\text { dry crude extract) }\end{array}$ & $\begin{array}{l}\text { Total phenolic } \\
\text { contents (mg GAE /g } \\
\text { dry crude extract) }\end{array}$ & $\begin{array}{l}\text { Gallic acid } \\
(\mu \mathrm{g} / \mathrm{g} \text { dry crude } \\
\text { extract) }\end{array}$ & $\begin{array}{l}\text { Proto-catechuic } \\
\text { acid ( } \mu \mathrm{g} / \mathrm{g} \text { dry } \\
\text { crude extract) }\end{array}$ & $\begin{array}{l}\text { Capsaicin } \\
(\mu \mathrm{g} / \mathrm{g} \text { dry } \\
\text { crude } \\
\text { extract) }\end{array}$ \\
\hline $\begin{array}{l}\text { 0\% ethanol } \\
\text { (Water) }\end{array}$ & $87.37 \pm 0.75^{\mathrm{a}}$ & $0.003 \pm 0.000^{\mathrm{a}}$ & $2.00 \pm 0.24^{c}$ & $23.225 \pm 8.545^{\mathrm{a}}$ & $63.31 \pm 1.47^{\mathrm{c}}$ & $\mathbf{0}$ \\
\hline $50 \%$ ethanol & $67.39 \pm 1.80^{b}$ & $0.424 \pm 0.043^{b}$ & $18.24 \pm 0.32^{b}$ & $65.450 \pm 2.590^{b}$ & $13.31 \pm 1.55^{a}$ & $353.12 \pm 10.52^{\mathrm{a}}$ \\
\hline $95 \%$ ethanol & $91.91 \pm 0.65^{\mathrm{a}}$ & $0.838 \pm 0.096^{c}$ & $24.63 \pm 0.81^{a}$ & $9895.75 \pm 159.93^{c}$ & $39.79 \pm 0.82^{b}$ & $815.14 \pm 31.60^{b}$ \\
\hline
\end{tabular}

All data are present as mean \pm SD of 3 replicates.

Values in the same column followed by the same lowercased letter are not significantly different by Duncan's Multiple-Rage Test ( $p$-value < 0.05).

(A)

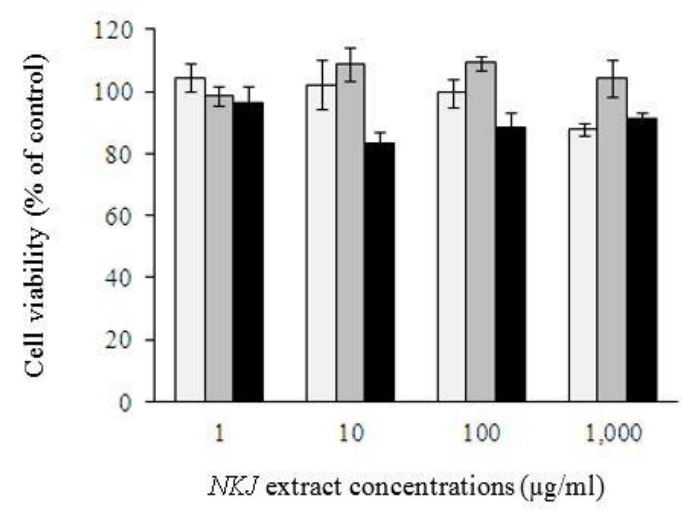

(B)

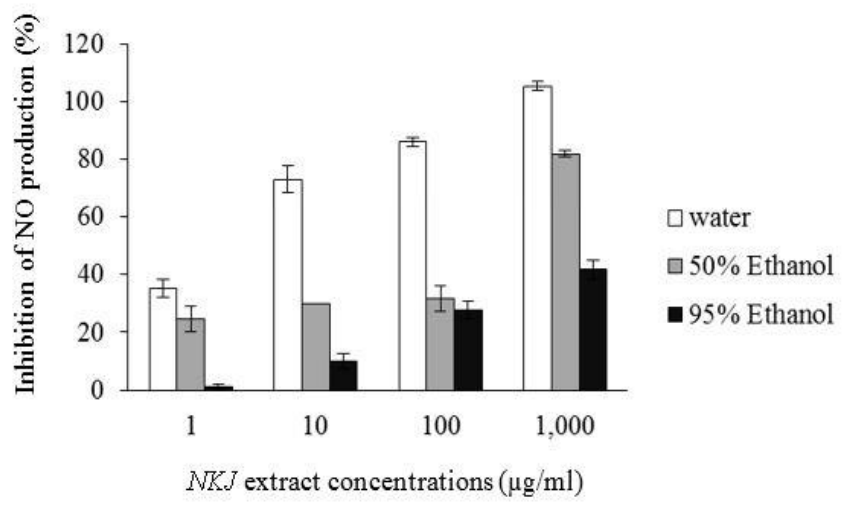

Figure 1. Cell viability (\%) (A) and inhibition of NO production (\%) (B) on LPS-induces RAW264.7 macrophage cells at various concentration of $N K J$ water/ethanol extracts. 


\section{Total phenolic content, antioxidant and anti-inflammatory properties}

Total phenolic contents (TPC) of NKJ extracts in water, 50\% ethanol, and 95\% ethanol varied considerably (Table 2), with $95 \%$ ethanol extract highest of TPC (24.63 $\pm 0.81 \mathrm{mgGAE} / \mathrm{g}$ dry crude extract) and water extract the lowest TPC $(2.00 \pm 0.24 \mathrm{mg}$ GAE /g dry crude extract) with significant difference. This reversal trends with radical scavenging (DPPH) property but aligned with reducing (FRAP) property (Table 1). For example, the antioxidant activity by DPPH was only $13.39 \pm 1.23 \%$ in $95 \%$ ethanol extract with the highest TPC and water extract exhibited the highest inhibition of DPPH with value of $68.34 \pm 5.11 \%$ (at $1 \mathrm{mg}$ crude extract $/ \mathrm{ml}$ ) where TPC was the lowest.

Total phenolic content might have relationship with antioxidant activity in some plants or food sources but not all of TPC related to antioxidant activity [33]. However, the best way to evaluate the level of TPC is based on the combination of the quantity and quality of their chemical structure [34]. In this study, as anticipated, the water polar compounds of phenolic demonstrate high quality of antioxidant activity or non-phenolic substances, which are responsible for antioxidant activity in this food.

The water-soluble compounds such as HCA in Garcinia Combogia have effective scavenger activity. This finding agrees with Shivakumar et al [35] who reported that hydro-alcoholic (60:40) extracts of Garcinia Combogia. L. possesses the highest antioxidant activity followed by ethanol, and hexane with DPPH method. On the other hand, the extract of Garcinia Combogia. L. demonstrated low activity by FRAP assay in all solvent extraction (hydro-alcohol, ethanol and hexane) for that study [35]. These results are unsurprising, as different assays function through different mechanisms and would thereby yield different results depending on the type of antioxidant present in the sample. Accordingly, the FRAP and DPPH assays may or may not correlate depending on the food system being tested.

\section{Identification of phenolic compounds by HPLC}

Identification of selected phenolic compounds by HPLC in reverse phase conditions revealed how gallic acid was a predominant component in 95\% ethanol (by several orders of magnitude). In contrast, for the crude water extract, gallic acid, and protocatechuic acid (PCA), there was no capsaicin found (Table 2). A previous study reported how PCA demonstrated the potential to be an antioxidative activity by both chelating metal transition ions and by scavenging free radicals via donating hydrogen atom or electron [36].

In this study, the PCA in water extract might play a role on anti-inflammatory properties in water extract of $N K J$. However, it is likely there are other anti-inflammatory compounds not accounted for in this case that could have a more significant inhibitory effect. More study is warranted.

Inflammatory response is a complex phenomenon involving numerous mediators, a number of which are potentially affected by polyphenols, mostly in culinary herbs and spices [37]. There are two possible cellular pathways, including arachidonic dependent pathways and arachidonic independent pathways [38]. Arachidonic dependent pathways are via the action of cyclooxygenase (COX) enzymes [39]. Apigenin from parsley has been shown to be related to this 
mechanism that might stop the inflammation process [40]. Arachidonic independent pathways can involve phenolic compounds. Peroxisome proliferator activated receptors (PPARs), NOS, and NF$\mathrm{\kappa B}$ are involved in the regulation of the expression of pro-inflammatory cytokines, including IL-8 [38]. Some polyphenols can inhibit the pro-inflammatory NF- $\mathrm{BB}$ pathway such as curcumin, a main bioactive compound in turmeric [41]. Curcumin has been focused on for its antiinflammatory properties and cancer prevention by detoxifying enzymes, preventing DNA damage, and decreasing mutations and tumor formation [42].

Many ingredients used in Thai foods contained antioxidant and anti-inflammatory substances that have been said to relieve oxidative stress [12]. Our finding suggests that bioactive compounds such as curcumin from turmeric (used in $N K J$ ) can similarly inhibit the inflammation process in the arachidonic independent pathway, which in turn reduces oxidative stress.

\section{CONCLUSION}

NKJ contains several bioactive water-soluble ingredients such as piperine from black pepper (Piper nigrum Linn), HCA from Garcenia Combogia, and bioactive peptide from fish. The ameliorating effects of oxidation and inflammation are attributed to the combined effects from these bioactive ingredients. The present study has demonstrated that aqueous and ethanol extract of $N K J$ (defatted) exerted antioxidant and anti-inflammatory activities in in vitro model. The crude water extracts of $N K J$ which contained the highest amount total phenolic exhibited relatively lower antioxidant activity but showed a high potential effect on inflammatory activity.

List of Abbreviations: NKJ, Namya Kanom Jeen; ROS, reactive oxygen species; RNS, reactive nitrogen species; NO, nitric oxide; iNOS, inducible nitric oxide synthase; RPMI, Roswell Park Memorial Institute; FRAP, Ferric Reducing Antioxidant Power; LPS, lipopolysaccharides; OD optical density; TPC, total phenolic content; HPLC, high-performance liquid chromatography; DPPH, free radical scavenging capacity; HCA, hydroxyl citric acid; GAE, gallic acid equivalent; PCA, protocatechuic acid.

Author Contributions: Pavinee Chinachoti, Rattana Leelawattana and Preeya Dat-arun designed the research. Pavinee Chinachoti conducted the research while she was a faculty member at PSU and wrote the manuscript. All authors read and approved the final version of the manuscript.

Competing Interests: There are no conflicts of interest to declare.

Acknowledgements and Funding: This work was supported by the Higher Education Research Promotion and National Research University Project of Thailand, Office of the Higher Education Commission.

\section{REFERENCES}

1. Pham-Huy LA, He H, Pham-Huy C: Free radicals, antioxidants in disease and health. Int J Biol Sci 2008, 4(2): 89-96. 
2. Valko M, Leibfritz D, Moncol J, Cronin MTD, Mazur M, Telser J: Free radicals and antioxidants in normal physiological functions and human disease. Int $\mathrm{J}$ Biochem Cell Biol 2007, 39(1):44-84.

3. Pittella E, Dutra RC, Junior DD, Lopes MTP, Barbosa NR: Antioxidant and cytotoxic activity of Centellaasiatica (L) Urb. Int J Mol Sci 2009, 10: 3713-3721.

4. Reuter S, Gupta SC, Chaturvedi MM, Bharat B, Aggarwal BB: Oxidative stress, inflammation and cancer: how are they linked?: Free Radic Biol Med 2010, 49:16031616.

5. Lobo V, Patil A, Chandra N: Free radicals, anti-oxidant and functional foods: impacts on human health. Pharmacogn Rev 2010, 4:118-126.

6. Biesalski HK: Polyphenols and inflammation: basic interactions. Curr Opin Clin Nutr Metab Care 2007, 10:724-728.

7. Prior RL, Wu X, Schaich K: Standardized methods for determination of anti-oxidant capacity and phenolics in foods and dietary supplements. J Agric Food Chem 2005, 53:4290-4302.

8. Watson JD: Type 2 diabetes as a redox disease. Lancet 2014, 383:841-843.

9. Sen S, Chakraborty R, Sridhar C, Reddy YSR, De B: Free radicals, anti-oxidants, diseases and phytomedixines: current status and future prospect. Int J Pharm Sci Rev Res 2010, 3:91-100.

10. Aggarwal BB, Van Kuiken ME, Iyer LH, Harikumar KB, Sung B: Molecular targets of nutraceuticals derived from dietary spice: potential role in suppression of inflammation and tumorigenesis. Exp Biol Med 2009, 234:825-849.

11. Hayouni E, Abedrabba M, Bouix M, Hamdi M: The effect of solvents and extraction method on the phenolic compounds contents and biological activities in vitro of Tunisian Quercus coccifera L. and Juniperus phoenicea L. fruit extract. J Food Chem 2007, 105:1126-1134.

12. Tuntipopipat S, Muangnoi C, Chingsuwanrote P, Parengam M, Chantravisut P, Charoenkiatkul S, Svasti S: Anti-inflammatory activities of red curry paste extract on lipopolysacchaide-activated murine macrophage cell line. Nutrition 2011, 27: 479-487.

13. Prangthip P, Charoenkiatkul S, Kettawan A, Okuno M, Okamoto T: Thai red curry paste lowers glucose, oxidative stress and insulin levels in type II diabetic rats. Int Food Res J 2012, 2:623-627.

14. Dat-arun P: Anti-oxidative and anti-inflammatory properties of traditional Southern Thai food extracts and their influences on biomarkers of glucose metabolism: Ph.D. Dissertation, Department of Functional Food and Nutrition, Prince of Songkla University, Thailand 2016: 191p.

15. Charoenkiatkul S, Dissayabutr W, Boonpraderm A, Titatan Y, Ruamruk M: Development of Thai set menu. Research report submitted to Thailand National Research Council; 2005.

16. AOAC: Official methods of analysis, 17th ed. Gaithersberg, Maryland: Association of Official Analytical Chemists; 2000. 
17. Maeda H, Satoh T, Islam WM: Preparation of function-enhanced vegetable oils. Func food health dis 2016, 6 (1): 33-41.

18. Sivarao N, Kumar N, Widodo WS, Haeryip S: Hexane economization in palm kernel oil plant: a study after process design improvement. Global Engineers and Technologists Review 2012, 2(12):7-14.

19. Kumar K, Yadav AN, Kumar V, Vyas P, Dhaliwal HS: Food waste: a potential bioresource for extraction of nutraceuticals and bioactive compounds. Bioresources and Bioprocessing 2017, 4(18): 2-14.

20. Brand-Williams W, Cuvelier ME, Berset C: Use of a free radical method to evaluate antioxidant activity, Lebensm-Wiss. U.-Technologie. Food Sci Technol 1995, 28:25-30.

21. Benzie IF, Strain JJ: The ferric reducing ability of plasma (FRAP) as a measure of antioxidant power: the FRAP assay. Anal Biochem 1996, 239:70-76.

22. Tewtrakul S, Subhadhirasakul S, Karalai C, Ponglimanont C, Cheenpracha S: Antiinflammatory effects of compounds from Kaempferia parviflora and Boesenbergia pandurate. Food Chem 2009, 115:534-538.

23. Yamamoto Y, Kobayashi Y, Devi SR, Rikiishi S, Matsumoto H: Aluminum toxicity is associated with mitochondrial dysfunction and the production of reactive oxygen species in plant cells. Plant Physiol 2002, 128:63-72.

24. Manaharan T, Appleton D, Cheng HM, Palanisamy UD: Flavonoids isolated from Syzygium aqueum leaf extract as potential antihyperglycaemic agents. Food Chem 2012, 132:1802-1807.

25. Slinkard K, Singleton VL: Total phenol analyses: automation and comparison with manual methods. Am J Enol Vitic 1997, 28:49-55.

26. Merken HM, Beecher GR: Liquid chromatographic method for the separation and quantification of prominent flavonoid aglycones 3. J Chromatogr A 2000, 897:177-184.

27. Tian S, Nakamura K, Kayahara H: Analysis of phenolic compounds in white rice, brown rice and germinated brown rice. J Agric Food Chem 2004, 52:4808-4813.

28. Othman ZA, Ahmed YB, Habila MA, Ghafar AA: Determination of capsaicin and dihydrocapsaicin in Capsicum fruit samples using high performance liquid chromatography. Molecules 2011, 16:8919-8929.

29. Tilahun S, Paramaguru P, Rajamani K: Capsaicin and ascorbic acid variability in chili and paprika cultivars as revealed by HPLC analysis. J Plant Breed Genet 2013, 1:85-89.

30. Banerjee SK, Mukherjee PK, Maulik SK: Garlic as an anti-oxidant: the good, the bad and the ugly. Phytother Res 2003, 17:97-106.

31. Liu Q, Zhang YJ, Yang CR, Xu M: Phenolic anti-oxidants from green tea produced from Camellia crassicolumna Var. multiplex. J Agric Food Chem 2009, 57:586-590.

32. Yamada T, Hida H, Yamada Y: Chemistry, physiological properties and microbial production of hydroxycitric acid. Appl Microbiol Biotechnol 2007, 75:977-998.

33. Oliveira AMF, Pinheiro LS, Pereira CKS, Matias WN, Gomes RA, Chaves OS, Souza MFV, et al.: Total phenolic content and anti-oxidant activity of some Malvaceae family species. Anti-oxidants 2012, 1:33-43. 
34. Nisar R, Baba WN, Masoodi FA: Effect of chemical and thermal treatments on quality parameters and anti-oxidant activity of apple (pulp) grown in high Himalayan regions. Cogent Food and Agriculture 2015, 1:1063797. DOI: http://dx.doi.org/10.1080/ 23311932.2015.1063797

35. Shivakumar S, Sandhiya S, Subhasree N, Agrawal A, Dubey GP: In vitro assessment of antibacterial and anti-oxidant activities of fruit rind extracts of Garcinia Cambogia. L. Int J Pharm Sci 2003, 5:254-257.

36. Li X, Wang X, Chen D, Chen S: Anti-oxidant activity and mechanism of protocatechuic acid in vitro. Func food health dis 2011, 7:232-244.

37. Sindhu RK, Koo JR, Roberts CK, Vaziri ND: Dysregulation of hepatic superoxide dismutase, catalase and glutathione peroxidase in diabetes: response to insulin and antioxidant therapy. Clin Exp Hypertension 2004, 26:43-53.

38. Quinn L: Mechanism in the development of type 2 diabetes mellitus. J Cardiovas Nursing 2002, 16:1-16.

39. Gaal LV, Scheen A: Weight management in Type 2 Diabetes: current and emerging approaches to treatment. Diabetes care 2015, 38:1161-1172.

40. Reid J, MacDougal AI, Andrews MM: Aspirin and diabetes mellitus. Br Med J 1957, 2: 1071-1074.

41. Yoon JH, Baek SJ: Molecular targets of dietary polyphenols with anti-inflammatory properties. Yonsei Med J 2005, 46: 585-596.

42. Griffiths K, Aggarwal BB, Singh RB, Buttar HS, Wilson D, De Meester F: Food antioxidants and their anti-inflammatory properties: a potential role in cardiovascular diseases and cancer prevention. Edited by Battino M. Diseases 2016, 4(3): 28. DOI: https://doi.org/10.3390/diseases4030028. 